\title{
TECHNICAL FEATURES OF THE COMMERCIAL BROILER BREEDER SYSTEM IN EGYPT
}

\author{
Y. A. Abdel Aziz ${ }^{1}$, A. M. Atta ${ }^{2}$ and N.E. Goher ${ }^{2}$ \\ 1- Animal Production Research Institute, Ministry of Agriculture and Land \\ Reclamation, Dokki, Giza, Egypt, 2- Animal Production Department, Faculty of \\ Agriculture, Cairo University, Giza, Egypt
}

\section{SUMMARY}

This work is based on a systems approach in the characterization and analysis of the broiler breeder production system. Data of nineteen complete production cycles were collected from Misr Arab and El-Rabie farms over the period 1993-2000. Cycles started in two different seasons, winter and summer. Five strains were used, namely Arbor Acres, Avian, Hubbard, Isa, and Lohman. Means for major technical characteristics and budget variables were estimated. The list of means included flock size (28479 hens), number of hen/housed (26478 hens), length of rearing period (25.7 $w k)$, length of production period (42.5 wk), uniformity (91\%), loss (5.5\%), hatchability (81\%), egg production/hen (171 eggs), hatchable eggs/hen (156), salable chick/hen (128), feed consumption/ produced egg (268 g), per fertile egg (281 g), and per produced chick $(353 \mathrm{~g})$.

Keywords: Broiler breeder production system, commercial system, technical factors

\section{INTRODUCTION}

Commercial poultry industry in Egypt has started some 40 years ago. Broiler breeder production is relatively new. Management of the broiler breeder has become a specialized task, and to our knowledge there is no previous attempt to highlight the different factors influencing this type of production.

In this study, a system approach was used to provide a basis for understanding of the range of factors that can influence the broiler breeder production system.

\section{MATERIAL AND METHODS}

\section{Data}

The collected data were recorded over a period of eight years (1993-2000, inclusive) from two farms, Misr Arab Poultry Company (MA), and El-Rabie Poultry Company (ER). The farms are located at El-Sadat City and Regwa Region, respectively. Both farms are at about $120 \mathrm{~km}$ Northwest of Cairo off Cairo-Alexandria desert road. Five strains were used, Arbor-Acres (A), Avian (V), Hubbard (H), Isa (I), and Lohman (L). The production cycles were executed in two different seasons, Sept. - Feb. (W) and March- August (S). Data comprised information on technical performance of 19 complete broiler breeder production cycles. The recorded data separated the rearing phase from the laying phase. The data included technical information on both phases.

Issued by The Egyptian Society of Animal Production 


\section{Description of farms}

The site of each company consists of four farms. Each farm has eight open sided houses with gable roof. The dimensions of the houses are $10 \mathrm{~m}$ width $\mathrm{x} 100 \mathrm{~m}$ length $\mathrm{x}$ $3 \mathrm{~m}$ height. The distance between farms is $500 \mathrm{~m}$, and the distance between houses within farm is $30 \mathrm{~m}$.

\section{Management System \\ 1- General management}

The life cycle of parent stock consists of two phases, rearing and production. The main purpose of the rearing phase is to achieve the targeted body weight and uniformity of each broiler breeder strain. Random samples of about $5 \%$ of the birds were weighed individually each week starting from three weeks of age. Weighing was done every week along the rearing life of the flock on the same day of the week and at the same time (in the morning before feeding). After weighing, average weight, uniformity and weekly weight gain were calculated. After three weeks of age, the flock was divided into three categories: 1) Light weight category, 2) Medium weight category, and 3) Heavy weight category.

Each category was offered different quantities of feed in order to reach targeted weight and uniformity (not less than $85 \%$ ) at 20 weeks with an even growth curve within the production standard. During the production stage birds of a sample of about $1 \%$ of the total number of birds were weighed each two weeks, whereas a sample of $1 \%$ eggs were individually weighed weekly. The challenge feed or decreased daily feed intake was designed according to body weight, egg production and egg weight.

\section{2- Feeding}

During the first four weeks of age birds were fed on starter breeder ration $(20 \% \mathrm{CP}$, $1 \% \mathrm{Ca}$ and $2800 \mathrm{ME} \mathrm{kcal} / \mathrm{kg}$ ). $>$ From 5 to 18 weeks of age, birds were fed on grower ration $(15 \% \mathrm{CP}, 1 \% \mathrm{Ca}$ and $2650 \mathrm{ME} \mathrm{kcal} / \mathrm{kg})$. $>$ From $19-23$ weeks of age pre-breeder ration $(16-17 \mathrm{CP}, 1.4 \mathrm{Ca}$ and $2700 \mathrm{ME} \mathrm{kcal} / \mathrm{kg}$ ) was provided. Thereafter, the birds were fed breeder ration (16-17\% CP 3.3\% Ca and $2750 \mathrm{ME} \mathrm{kcal} / \mathrm{kg})$. During the first two weeks of ages, the females were fed $a d$ lib. Then feed was restricted according to the actual body weight, weekly weight gain, uniformity and feed recommended of each strain. The males were fed ad lib during the first four weeks of age after which restricted feeding program was followed.

\section{3- Mating}

Males were separately reared until 22 weeks of age, then 10 males were joined with each group of 100 females.

\section{Statistical Analysis}

\section{1- Estimation of descriptive statistics}

In order to characterize the studied production system, means, standard deviations, and minimum and maximum values were estimated for technical variables which would provide information for describing the system.

\section{2- Least squares analysis of variance (ANOVA).}

Data on mortality and hatchability were analyzed according to the Least Squares Mixed Model and Maximum Likelihood Computer Program (Harvey, 1990). The following statistical model was assumed to underlie the ANOVA and estimating the least squares means. The model was of the general form:

$\mathrm{Y}_{\mathrm{ijk}}=\mu+\mathrm{s}_{\mathrm{i}}+\mathrm{r}_{\mathrm{i}}+\mathrm{m}_{\mathrm{k}}+\mathrm{b}_{1}\left(\mathrm{n}_{1}-\overline{\mathrm{n}}_{1}\right)+\mathrm{b}_{2}\left(\mathrm{n}_{2}-\overline{\mathrm{n}}_{2}\right)+\mathrm{e}_{\mathrm{ijk}}$ 
Where $Y_{\mathrm{ijk}}$ is mortality, or hatchability,

$\mu=$ is a general mean

$\mathrm{s}_{\mathrm{i}}=$ fixed effect of the $\mathrm{i}^{\text {th }}$ strain, $\mathrm{i}=1,2, \ldots \ldots, 5$

$r_{i}=$ fixed effect of the $j^{\text {th }}$ year, $j=1,2, \ldots \ldots ., 8$

$\mathrm{m}_{\mathrm{k}}=$ fixed effect of the $\mathrm{k}^{\text {th }}$ season, $\mathrm{k}=1,2$

$b_{1}=$ the regression coefficient of $Y$ on flock size (the number of chicks $\left(n_{1}\right)$ at the beginning of the cycle).

$b_{2}=$ the regression coefficient of $Y$ on the duration of the cycle in days $\left(n_{2}\right)$, and

$e_{i \mathrm{jk}}$ is a random effect associated with the $Y_{\mathrm{ijk}}$ variable, and assumed to be random, independent, and normally distributed.

The least squares means were calculated and the differences between them were tested by Duncan's Multiple Range Test.

\section{RESULTS AND DISCUSSION}

\section{Characteristics of the Broiler Breeder' Production System}

Measures of production (outputs) and productivity (output in relation to input) represent an important tool for describing the system. The main variables that would characterize a system include measures of performance, which reflect the standard of management (Table 1).

\section{Technical characteristics}

It is acceptable that the system can be characterized using descriptive statistics, such as the arithmetic means, standard deviations, in addition to minimum and maximum values of certain variables. The characteristics of the system (Table 1) include input variables as well as output variables.

There exists a wide range of flock size and number of hen/housed estimates. Judged by the estimates of the standard error (SE) and the range between minimum and maximum values, it is evident that both rearing period and laying period are less variable.

Uniformity, defined as the percentage of pullets attaining targeted mean body weight, is an important criterion for the broiler breeder manager. Within the growing facilities, the manager would strive to obtain the highest uniformity possible. Most managers accept values of $80 \%( \pm 10 \%)$ to $85 \%( \pm 15 \%)$. Table (2) gives a higher value of about $91 \%$ for uniformity with a less standard deviation of only $1 \%$ which indicates adequate basic floor spacing, good feeding and watering management. Appropriate flock size and good vaccination programs are also reasons for improving flock uniformity. The attained results are in agreement with those reported by Lesson and Summers (2000).

\section{Analysis of variance (ANOVA) for mortality and hatchability}

Performance in the strict sense of broiler breeder production is directly affected by reproduction and viability. Performance also depends mainly on the environment which, in this study, is highly controlled. However, it results from an extremely complex set of interactions between genotype of the birds and their environment and it, in fact, characterizes the overall system. Two characters were chosen for analysis of variance: 1) hatchability which is a function of egg production, percentage of fertile eggs, and percentage of hatchable eggs; and 2) mortality, which is the opposite of viability. 
Table 1. Some characteristics of the studied broiler breeder system classified by strain

\begin{tabular}{|c|c|c|c|c|}
\hline Characteristic & Mean & S. D. & Minimum & Maximum \\
\hline & \multicolumn{4}{|c|}{ Arbor acres } \\
\hline Flock size (no.) & 32493 & 5935 & 17900 & 35350 \\
\hline Rearing period (wk) & 25.37 & 0.74 & 24.00 & 26.00 \\
\hline Hen housed (no.) & 30385 & 5785 & 16191 & 33293 \\
\hline Production period (wk) & 42.50 & 1.69 & 40.00 & 46.00 \\
\hline \multicolumn{5}{|l|}{ Number of cycles $=8$} \\
\hline & & & Avian & \\
\hline Flock size (no.) & 34902 & 285 & 34700 & 35104 \\
\hline Rearing period (wk) & 24.50 & 2.12 & 23.00 & 26.00 \\
\hline Hen housed (no.) & 33223 & 406 & 32936 & 33511 \\
\hline Production period (wk) & 44.00 & 4.24 & 41.00 & 47.00 \\
\hline \multicolumn{5}{|l|}{ Number of cycles $=2$} \\
\hline & & & Hubbard & \\
\hline Flock size (no.) & 26168 & 9538 & 17414 & 34990 \\
\hline Rearing period (wk) & 26.33 & 0.51 & 26.00 & 27.00 \\
\hline Hen housed (no.) & 23997 & 8735 & 15363 & 32502 \\
\hline Production period (wk) & 41.00 & 1.26 & 40.00 & 43.00 \\
\hline \multicolumn{5}{|l|}{ Number of cycles $=6$} \\
\hline & & & Isa & \\
\hline Flock size (no.) & 18139 & -- & 18139 & 18139 \\
\hline Rearing period (wk) & 26.00 & -- & 26.00 & 26.00 \\
\hline Hen housed (no.) & 16824 & -- & 16824 & 16824 \\
\hline Production period (wk) & 41.00 & -- & 41.00 & 41.00 \\
\hline \multicolumn{5}{|l|}{ Number of cycles $=1$} \\
\hline & \multicolumn{4}{|c|}{ Lohman } \\
\hline Flock size (no.) & 18102 & 165 & 17985 & 18219 \\
\hline Rearing period (wk) & 26.50 & 0.70 & 26.00 & 27.00 \\
\hline Hen housed (no.) & 16462 & 89 & 16399 & 16525 \\
\hline Production period (wk) & 41.50 & 0.70 & 41.00 & 42.00 \\
\hline Number of cycles $=2$ & & & & \\
\hline
\end{tabular}

Tables 3 and 4 show no significant effects of strain, year, season on mortality and hatchability at the given level of probability. Linear regression coefficients of each of the studied characters on flock size and duration of the cycle were also not significant at the same probability level. Duncan's Multiple Range Test showed only very few significant differences $(\mathrm{P}<0.05)$ between least squares means of hatchability among the different years. These results may be due to the strictly controlled environment in the pullet and chicken houses. Differences among strains were not significant because the several adjustments for number of cycles and other effects in the model underlying the ANOVA. 
Table 2. Technical characteristics of the studied broiler breeder system (based on 19 production cycles)

\begin{tabular}{lllll}
\hline Character & Mean & S.D. & Minimum & Maximum \\
\hline Flock size (no.) & 28479 & 8391 & 17414 & 35350 \\
Rearing period (wk) & 25.73 & 0.99 & 23.00 & 27.00 \\
Hen housed (no.) & 26487 & 8027 & 15363 & 33511 \\
Production period (wk) & 42.00 & 1.88 & 40.00 & 47.00 \\
Mortality (\%) & 5.56 & 2.32 & 3.14 & 10.45 \\
Uniformity (\%) & 91.29 & 1.17 & 90.00 & 93.00 \\
Feed consumption / bird (kg) ${ }^{(1)}$ & 13.99 & 1.10 & 11.25 & 15.55 \\
Total egg production/ cycle (no.) & 46180 & 16131 & 22024 & 65535 \\
Fertile eggs/ cycle (no.) & 44113 & 15287 & 21230 & 62634 \\
Hatchable eggs/cycle (no.) & 41794 & 13866 & 20753 & 58021 \\
Egg production/hen (no.) & 171.79 & 17.28 & 133.28 & 198.18 \\
Fertile eggs/ hen (no.) & 164.32 & 16.39 & 128.48 & 189.41 \\
Hatchable eggs/hen (no.) & 156.38 & 13.46 & 125.59 & 176.90 \\
Saleable chicks/hen (no.) & 128.23 & 13.29 & 94.25 & 154.10 \\
Fertility (\%) & 85.78 & 3.11 & 78.17 & 90.40 \\
Hatchability (\%) & 81.92 & 3.38 & 75.05 & 87.12 \\
Feed consumption/produced egg (gm.) & 268.17 & 30.32 & 220.00 & 341.00 \\
Feed consumption/ fertile egg (gm.) & 281.39 & 31.68 & 225.00 & 353.00 \\
Feed consumption/ produced chick & 353.30 & 35.87 & 284.00 & 410.00 \\
(gm.) & & & &
\end{tabular}

(1) Rearing period.

Table 3. Least squares analysis of variance (ANOVA) for mortality \%

\begin{tabular}{lllll}
\hline Source of variance & d.f. & MS & F-value & $\begin{array}{l}\text { Level of } \\
\text { probability (P) }\end{array}$ \\
\hline Strain & 4 & 17.03 & 1.18 & $0.43 \mathrm{NS}^{(2)}$ \\
Year & 7 & 5.83 & 0.41 & $0.85 \mathrm{NS}$ \\
Season & 1 & 0.00 & 0.00 & $0.99 \mathrm{NS}$ \\
Regression on flock size (b1) & 1 & 2.14 & 0.16 & $0.71 \mathrm{NS}$ \\
Regression on cycle duration (b2) & 1 & 17.61 & 1.22 & $0.33 \mathrm{NS}$ \\
Error & 4 & 14.38 & & \\
Total & 18 & & & \\
\hline
\end{tabular}

(1) $\mathrm{R}^{2}$ of the model $=0.90 \quad$ (2) $\mathrm{NS}=$ not significant at $\mathrm{P}<0.05$.

Table 4. Least squares analysis of variance (ANOVA) for hatchability \%

\begin{tabular}{lcccc}
\hline \multicolumn{1}{c}{ Source of variance } & d.f. & $\begin{array}{c}\text { MS } \\
\left.\mathbf{( 1 0}^{\mathbf{6}}\right)\end{array}$ & F-value & $\begin{array}{c}\text { Level of } \\
\text { probability (P) }\end{array}$ \\
\hline Strain (S) & 4 & 10.45 & 2.88 & $0.16 \mathrm{NS}^{(2)}$ \\
Year (R) & 7 & 10.31 & 2.62 & $0.18 \mathrm{NS}$ \\
Season (M) & 1 & 19.10 & 4.85 & $0.09 \mathrm{NS}$ \\
Regression on flock size (b1) & 1 & 2.71 & 0.69 & $0.45 \mathrm{NS}$ \\
Regression on cycle duration (b2) & 1 & 0.03 & 0.01 & $0.42 \mathrm{NS}$ \\
Error & 4 & 3.93 & & \\
Total & 18 & & \\
\hline (1) $\mathrm{R}^{2}$ of the model $=0.92$ & (2) $\mathrm{NS}=$ not significant at $\mathrm{P}<0.05$.
\end{tabular}




\section{ACKNOWLEDGEMENTS}

The authors wish to express their thanks to Dr. M .A El- Shafie, Member of the Board of Directors, and Director General of Misr EL-Arabia Poultry Company for providing the data used in this paper. Special thanks to Dr. Mohammed A. Ibrahim, Associate Professor of Animal Breeding for his help in the statistical analysis of the data. Finally our deep thanks to Dr. A. Mostafa Ahmed, Associate Professor of Animal Production Systems, Desert Research Center for his valuable consulting in this paper .

\section{REFERENCES}

Harvey, W.R., 1990. User's Guide for LSMLMY and MIXMDT, PCS version (mimeograph). Ohio State University, Columbus, $\mathrm{OH}$.

Lesson, S. J.D. Summers, 2000. Broiler Breeder Production. University Books, Guelf, Ontario, Canada. 
السمات القنية للإنتاج التجارى لأمهات بدارى التسمين في مصر

ياسر أحمد عبد العزيز، عبد الرحمن محمد عطا، نجيب الهلالى جوهر

1- معطة بحوث الإنتاج الحيوانس، وزارة الزراعة وإستصلاح الأراضى، الدقى، جيزة، مصر، 2- فسم الإتتاج الحيوانى، كلية الزراعة، جامعة القاهرة، جيزة، مصر لئرة

أجريت هذه الدراسة على بيانات مُسجلة لعدد 91 دورة إنتاج كاملة لإنتاج أمهات بدارى التسمين، في

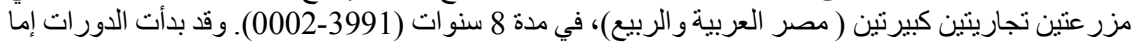

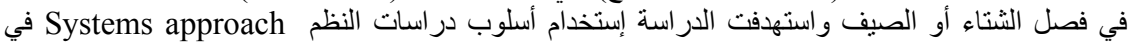

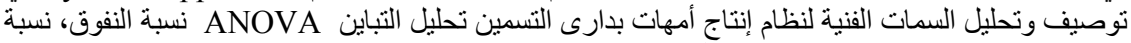

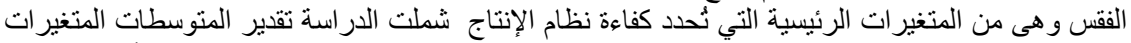

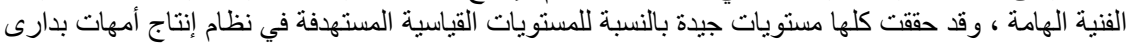

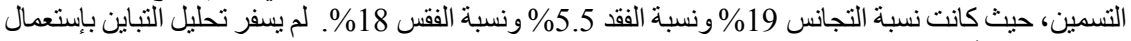

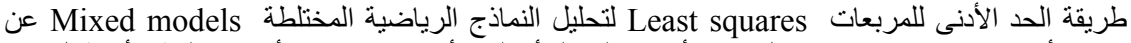

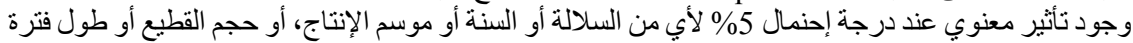
الإورة الإنتاج أو نسبة الفقد أو نسبة الفتس. وقد يعزى ذلك إلى التحكم الثنديد في كافة الظروف المحيطة بالعملية 